Рощина Н.В.

канд. економ. наук, дочент ORCID ID: 0000-0003-2035-8846

Національний технічний університет Украйни "Киїський політехнічний інститут імені Ігоря Сікорського"

Борданова Л.С.

канд.економ.наук

ORCID ID: 0000-0001-8159-3909

Національний технічний університет України "Київський політехнічний інститут імені Ігоря Сікорського"

Мілько І.В. канд. економ. наук ORCID ID: 0000-0002-5962-0082 Харківський національний економічний університет ім. С. Кузнеия

\title{
ОСОБЛИВОСТІ ЗАЛУЧЕННЯ ПРЯМИХ ІНОЗЕМНИХ ІНВЕСТИЦИЙ В ЕКОНОМІКУ УКРАЇНИ
}

\section{ОСОБЕННОСТИ ПРИВЛЕЧЕНИЯ ПРЯМЫХ ИНОСТРАННЫХ ИНВЕСТИЦИЙ В ЭКОНОМИКУ УКРАИНЫ}

\section{FEATURES ATTRACTING FOREIGN DIRECT INVESTMENT IN UKRAINE}

У статті проаналізовано поняття прямих іноземних інвестицій (ПІІ), визначені критерії інвестиційної привабливості країни та регіонів. Наведено дані динаміки міжнародної інвестиційної позичї Украӥни та динаміка надходження та відтоку іноземних інвестищій. На їх основі, а також на основі даних міжнародних рейтингів, було зроблено висновок про негативну інвестиційну ситуацію в Україні. Визначено низку негативних факторів, які $\epsilon$ чинниками погіршення інвестиційного клімату та в довгостроковій перспективі є перешкодами до зростання числа інвестицій в украӥнську економіку. Розглянуті галузі залучення іноземних інвестииій є пріоритетними з огляду на незбалансованість структури інвестицій, визначено питому вагу цих галузей у загальній структурі економіки. Запропонований ряд рекомендацій щзодо стимуляції залучення прямих іноземних інвестииій.

Ключові слова: прямі іноземні інвестиції, інвестиційний клімат, макроекономіка, інвестиційний потенціал, інвестиційна привабливість.

В статье проанализированы понятия прямых иностранных инвестиций (ПИИ), определенные критерии инвестиционной привлекательности страны и регионов. Приведены данные динамики международной инвестищионной позиции Украины и динамика поступления и оттока иностранных инвестиций. На их основе, а также на основе данных международных рейтингов, был сделан вывод о негативном инвестиционную ситуацию в Украине. Определен ряд негативных факторов, которые являются факторами ухудшения инвестиционного климата и в долгосрочной перспективе являются препятствиями к росту числа инвестиций в украинскую экономику. Рассмотрены области привлечения иностранных инвестиций, которые 
являются приоритетными, учитывая несбалансированность структуры инвестиций, определен удельный вес данных отраслей в общей структуре экономики. Предложено ряд рекомендаций по стимуляиии привлечения прямых иностранных инвестиций.

Ключевые слова: прямые иностранные инвестиции, инвестиционный климат, макроэкономика, инвестиционный потенщиал, инвестищионная привлекательность.

The article analyses the concept of foreign direct investment (FDI), certain criteria of investment attractiveness of the country and regions. The data of the dynamics of Ukraine's international investment position and the dynamics of the income and outflow of foreign investment. On this basis, and based on international ratings data, it was concluded that the negative investment situation in Ukraine. Identified a number of negative factors, which are factors in the deterioration of the investment climate in the long term, are obstacles to the growth of investments in the Ukrainian economy. We consider the region to attract foreign investment, which is a priority, given the imbalance in the structure of investments, determined the share of these sectors in the overall structure of the economy. It proposed a number of recommendations on stimulation of attraction of direct foreign investments.

Keywords: business model, start-up, monetization, investments, site, project, developer.

Вступ. 3 огляду на обрану тему дослідження доводити їі актуальність, на наш погляд, не є доцільним. На наш погляд, варто дослідити саме умови в яких відбувається процес залучення іноземних інвестицій та саме які галузі є найбільш пріоритетними в означеному процесі та в означених умовах господарювання. Якщо, дещо змінити ракурс визначення економічної природи іноземних інвестицій, то можна дістати висновку, що інвестиції - це своєрідний «попит», своєрідна «оцінка» результатів та процесів що відбуваються в економіці України з точки зору приросту капіталу та соціальної складової. Саме тому, у період макроекономічної нестабільності в Україні підвищення національної конкурентоспроможності та формування позитивного інвестиційного іміджу є вельми важливим завданням. Дефіцит капіталу в країні, потреба в науково-технічному прогресі та розвитку інституцій - все це, з одного боку, можливо вирішити, залучивши іноземні інвестиції, а 3 іншого боку - дані проблеми знижують інвестиційну привабливість держави. Тому, слід вирішити дану дилему, розробивши загальнодержавну стратегію стимулювання ПІІ, яка б мала на меті вирішення основного фундаментального завдання - створення стабільних та, відповідно, прогнозованих умов, що надавали можливість залучати необхідний обсяг надходжень у ті сфери економіки, які потребують модернізації та мають значну віддачу від інвестицій.

Дослідження особливостей процесу залучення прямих іноземних інвестицій на сучасному етапі розвитку економічних відносин знайшли своє відображення у низці праць українських і зарубіжних дослідників: Амоші, В. Василенка, О. Власюка, В. Волошина, О. Гаврилюка, П. Гайдуцького, В. Гейця, Б. Губського, Б. Данилишина, М. Денисенка, В. Загорського, I. Крейдич, Л. Шинкарук та ін. Проте постійні зміни умов господарювання та 
поява нових системоутворюючих чинників роблять даний напрям досліджень перманентно актуальним.

Постановка завдання. Метою статті $є$ дослідження особливостей залучення іноземних інвестицій в Україну на сучасному етапі розвитку економічних відносин.

Методологія. Для досягнення мети роботи було використано низку загальнонаукових і спеціальних методів дослідження, зокрема методи аналізу і синтезу, наукової дедукції та індукції, класифікаційно-аналітичний, прийоми логічного узагальнення тощо.

Результати дослідження. Прямими іноземними інвестиціями (foreign direct investment, FDI) є міжнародні інвестиції, здійснені резидентами в одній країні з метою реалізації своєї довгострокової зацікавленості в підприємствах іншої країни. За визначенням Міжнародного валютного фонду (МВФ) це закордонні інвестиції, величиною у понад як 10 відсотків статутного капіталу, що дає зацікавленій стороні право на участь в управлінні підприємством [1]. У Законі України «Про режим іноземного інвестування» іноземні інвестиції визначаються як «цінності, що вкладаються іноземними інвесторами в об'єкти інвестиційної діяльності 3 метою отримання прибутку або досягнення соціального ефекту» [2]. Мотивом для впровадженням урядом сприятливої інвестиційної політики $\epsilon$ загальне підвищення добробуту країни та відповідно ії іміджу на світовій арені. Завдяки залученню ПІІ створюються нові виробничі потужності, імпортуються новітні технології та збільшується кількість робочих місць.

Основні фактори, які визначають інвестиційну привабливість регіонів та країни загалом зображені на рис 1.

Для характеристики інвестиційної привабливості України доцільно буде використати дані чистої міжнародної інвестиційної позиції (англ. Net international investment position). Міжнародна інвестиційна позиція - це макроекономічне поняття, що означає загальний обсяг і структуру фінансових активів і зобов'язань країни перед нерезидентами. Міжнародна інвестиційна позиція є одним з елементів рахунку операцій з капіталом і є такі види активів, як акції, облігації, нерухомість і т. п. Чиста міжнародна інвестиційна позиція являє собою різницю між активами і зобов'язаннями країни (табл.1) [3].

Якщо чиста міжнародна інвестиційна позиція країни позитивна, то країна $\epsilon$ чистим кредитором по відношенню до решти світу, а якщо вона негативна то чистим боржником. Як ми бачимо Україна більше залучає інвестицій, ніж сама інвестує в інші економіки. 


\section{ОСНОВНІ ФАКТОРИ ВИЗНАЧЕННЯ ІНВЕСТИЦЙНОЇ ПРИВАБЛИВОСТІ}

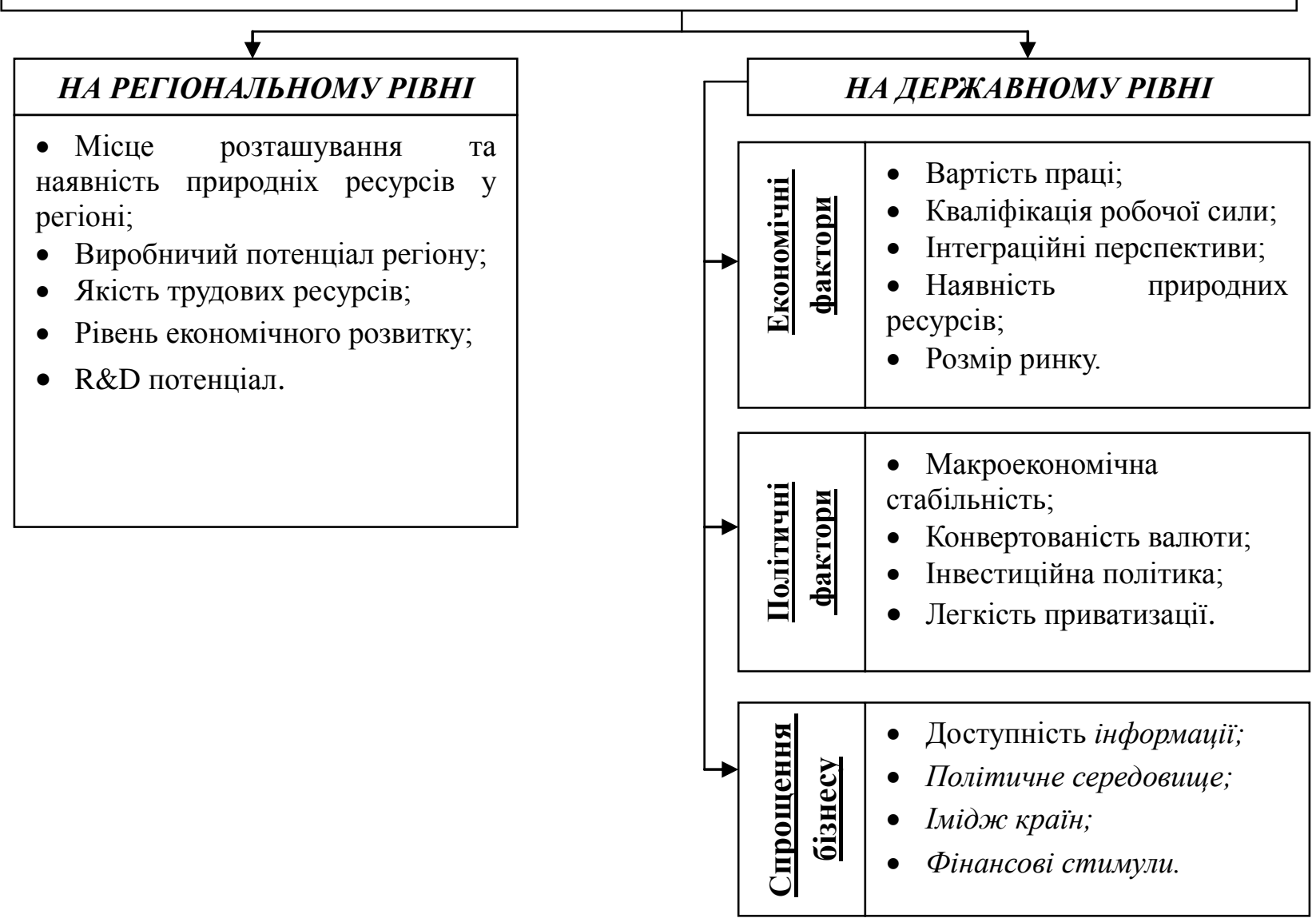

Рис. 1. Основні фактори визначення інвестиційної привабливості регіону та країни

Таблиия 1

Динаміка міжнародної інвестиційної позиції України, млн. дол.

\begin{tabular}{|l|c|c|c|c|c|c|}
\hline & Позиція & Позиція & Позиція & Позиція & Позиція & Позиція \\
\hline & $\begin{array}{c}\text { на } \\
\mathbf{0 1 . 0 1 . 2 0 1 1}\end{array}$ & $\begin{array}{c}\text { на } \\
\mathbf{0 1 . 0 1 . 2 0 1 2}\end{array}$ & $\begin{array}{c}\text { на } \\
\mathbf{0 1 . 0 1 . 2 0 1 3}\end{array}$ & $\begin{array}{c}\text { на } \\
\mathbf{0 1 . 0 1 . 2 0 1 4}\end{array}$ & $\begin{array}{c}\text { на } \\
\mathbf{0 1 . 0 1 . 2 0 1 5}\end{array}$ & $\begin{array}{c}\text { 3a 3 кв } \\
\mathbf{2 0 1 6}\end{array}$ \\
\hline Активи & 133426 & 139860 & 143697 & 138131 & 122500 & 123667 \\
\hline Пасиви & 172211 & 187808 & 203144 & 214979 & 185623 & 176423 \\
\hline $\begin{array}{l}\text { Чиста } \\
\text { міжнародна } \\
\text { інвестиційна } \\
\text { позиція }\end{array}$ & -38785 & -47948 & -59447 & -76848 & -63123 & -52756 \\
\hline
\end{tabular}

Джерело: Державна служба статистики України[5]

Загальний обсяг прямих іноземних інвестицій у вигляді акціонерного капіталу на 1 жовтня 2016 р. склав 45,152 млрд дол. (табл.2), що в значній мірі менше ніж обсяг прямих іноземних інвестицій у 2014році. Це зумовлено 
економічною та політичною нестабільністю в країні, прогалинами в інвестиційному законодавстві, відсутністю належного інституційного забезпечення розвитку інвестиційного ринку, сильний податковий тиск.

Таблиия 2

Динаміка надходження та відтоку ПІІ з України, млн. дол.

\begin{tabular}{|c|c|c|}
\hline $\begin{array}{c}\text { Станом на } \\
\mathbf{0 1 . 0 1}\end{array}$ & $\begin{array}{c}\text { Прямі іноземні інвестиції в } \\
\text { Україну }\end{array}$ & Прямі інвестиції з України \\
\hline 2011 & 43836,80 & 6846,30 \\
\hline 2012 & 48991,40 & 6878,90 \\
\hline 2013 & 53679,30 & 6462,60 \\
\hline 2014 & 57056,40 & 6597,40 \\
\hline 2015 & 45744,80 & 6350,60 \\
\hline 2016 & 45152,20 & 6236,90 \\
\hline
\end{tabular}

Джерело: Державна служба статистики України [5]

Цими ж причинами пояснюється факт, що обсяг ПІІ в Україні 3 розрахунку на душу населення становить 1058 доларів США [5], що в декілька разів менше аналогічних показників в країнах Центральної та Східної Європи (у Чехії - 7418 дол., Болгарії - 6226 дол., Польщі - 3155 дол.) [6].

Таблиия 3

Прямі іноземні інвестиції (акціонерний капітал) із країн світу в економіці України, млн.дол.

\begin{tabular}{|c|c|c|c|c|}
\hline & нa 01.10.2013 & Ha 01.10.2014 & нa 01.10.2015 & Ha 01.10.2016 \\
\hline $\begin{array}{c}\text { Усього у тому } \\
\text { числі }\end{array}$ & 56565,2 & 48522,6 & 43949,4 & 45152,2 \\
\hline Кіпр & 18712,0 & 15119,6 & 12187,6 & 11035,1 \\
\hline Нідерланди & 5504,0 & 5209,2 & 5702,0 & 5910,7 \\
\hline Німеччина & 6194,8 & 5769,6 & 5460,4 & 5446,0 \\
\hline $\begin{array}{c}\text { Російська } \\
\text { Федерація }\end{array}$ & 3842,1 & 2957,2 & 2962,8 & 4618,7 \\
\hline Австрія & 3216,4 & 2676,0 & 2639,6 & 2601,1 \\
\hline Велика Британія & 2724,4 & 2326,4 & 1948,7 & 1888,0 \\
\hline $\begin{array}{c}\text { Віргінські Острови } \\
\text { (Брит.) }\end{array}$ & 2452,4 & 2005,3 & 1863,3 & 1793,1 \\
\hline Франція & 1843,0 & 1648,2 & 1547,2 & 1533,2 \\
\hline Швейцарія & 1277,5 & 1393,9 & 1369,5 & 1475,4 \\
\hline Італія & 1259,0 & 1047,0 & 969,1 & 1158,2 \\
\hline Польща & 831,8 & 821,9 & 565,1 & 789,4 \\
\hline США & 985,8 & 886,6 & 793,4 & 712,6 \\
\hline Беліз & 1036,6 & 736,7 & 704,9 & 540,3 \\
\hline Інші країни & 6685,4 & 5925,0 & 551,4 & 4859,5 \\
\hline
\end{tabular}

Джерело: Державна служба статистики України[5] 
Інвестиції надійшли зі 125 країн світу. До десятки основних країнінвесторів, на які припадає $83,1 \%$ загального обсягу прямих інвестицій, входять: Кіпр - 11 млрд дол., Нідерланди - 5,9 млрд дол., Німеччина - 5,4 млрд дол., Російська Федерація - 4,6 млрд дол., Австрія - 2,6 млрд дол., Велика Британія - 1,9 млрд дол., Віргінські Острови (Брит.) - 1,8 млрд дол., Франція - 1,5 млрд дол., Швейцарія - 1,4 млрд дол. та Італія - 1,15 млрд дол. (табл. 3).

Покращити інвестиційний клімат країни можливо за рахунок різноманітних заходів, зокрема забезпечення чіткого правового поля інвестиційної діяльності, макроекономічної та політичної стабільності, запровадження податкових та митних пільг, дотацій, субсидій, субвенцій i бюджетних позик на розвиток пріоритетних сфер галузей економіки, подолання бюрократичних бар'єрів, корупції, забезпечення правового захисту інвестицій, покращення інформаційного забезпечення та інвестиційної інфраструктури.

3 метою поліпшення інвестиційного клімату необхідно провести ефективну політику зі зниження інфляції та інфляційних очікувань, а також врегулювати проблему державного боргу, забезпечити процедуру захисту прав власників та інвесторів. Тобто, створити такі сприятливі умови, при яких підвищиться міжнародний імідж країни, а інвестор буде зацікавлений працювати на території України на довгострокову перспективу. Також, слід зазначити, що головним завданням залучення іноземних інвестицій є сприяння довгостроковим цілям розвитку та підвищення конкурентоспроможності. Більш того, необхідно забезпечити чіткий зв'язок між політикою залучення іноземних інвестицій та промисловою політикою. Тому пільги щодо ПІІ повинні розроблятися та надаватися урядом виходячи 3 планів відносного того, який промисловий пейзаж країна хотіла б мати в майбутньому [7].

Таблиия 4

Прямі інвестиції з України в економіці країн світу, млн. дол.

\begin{tabular}{|l|c|c|c|c|}
\hline & $\mathbf{2 0 1 3}$ рік & $\mathbf{2 0 1 4}$ рік & $\mathbf{2 0 1 5}$ рік & $\mathbf{2 0 1 6}$ рік \\
\hline Кіпр & 5818,4 & 5819,4 & 5817,6 & 5824,8 \\
\hline Російська Федерація & 360,4 & 254,7 & 134,5 & 139,2 \\
\hline Латвія & 96,9 & 88,9 & 76,9 & 70,8 \\
\hline Польща & 55,5 & 53,6 & 50,3 & 50,2 \\
\hline Віргінські Острови (Брит.) & 25,8 & 25,8 & 52,0 & 52,0 \\
\hline Інші країни & 153,2 & 118,6 & 100,7 & 99,9 \\
\hline
\end{tabular}

Джерело: Державна служба статистики України[5]

Найбільші обсяги інвестиційного капіталу $(78,9$ \% від загального обсягу ПІІ) надходять в Україну з Свропейського Союзу (СС) (рис. 2). 


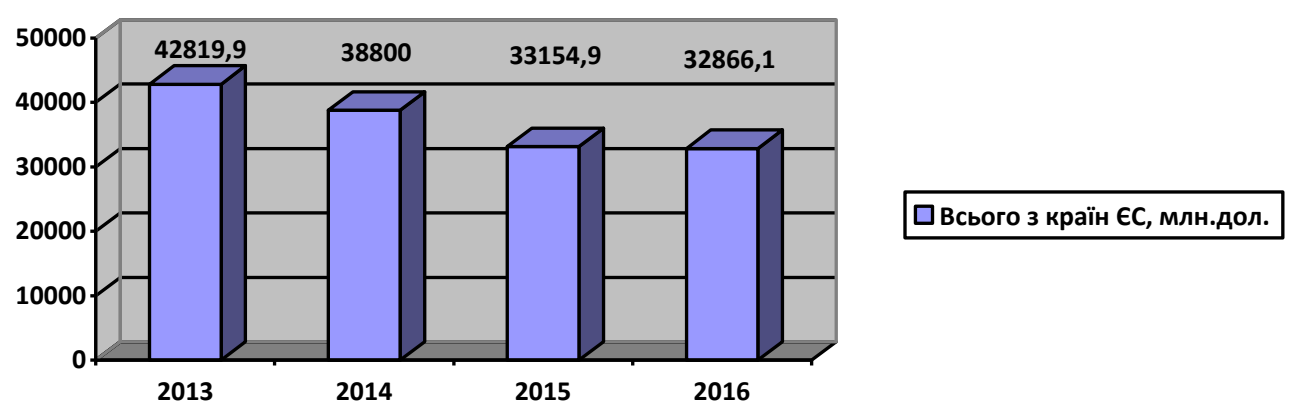

Рис. 2. Прямі іноземні інвестиції в економіці України з країн СС

Існують припущення, що метою інвестування для багатьох іноземних інвесторів поки що $\epsilon$ використання українського ринку для отримання швидкого прибутку. Сьогодні існує схильність інвесторів до фінансових зловживань і відмиванням коштів. Високий ступінь інвестування 3 таких країн, як Віргінські острови та Нідерланди пояснюється суттєвими пільгами для зареєстрованих у них іноземних компаній, а значить, їм притаманні певні елементи офшорності, проте неспівставні з Кіпром. Режим офшорної зони, що діє на Кіпрі, сприяв здійсненню з території острова т. зв. «опосередкованих» ПІІ, які значно перевищують власні кіпрські інвестиції. За попередніми оцінками, значну частину ПІІ 3 Кіпру здійснюють дочірні структури українських фірм. Основними галузевими пріоритетами вкладення інвестицій вище вказаних країн $\epsilon$ фінансова та страхова діяльність, операції з нерухомим майном, оптова та роздрібна торгівля, інформація та телекомунікації, харчова та хімічна промисловість, металургійне виробництво, виробництво гумових та пластмасових виробів, машинобудування та ін. [8].

Наведені статистичні дані дають підстави для висновку, що саме країни ЄС здійснюють найбільший вплив на стан і динаміку інвестиційних процесів в Україні. Свропейський Союз $є$ інтеграційним ядром, навколо якого формуються ключові економічні й політичні процеси всієї Європи. Номінальна частка країн СС у ВВП світу складає 23,1 \% [9]. Також на країни ЄC припадає понад $40 \%$ золотовалютних ресурсів і зовнішньоторгового обороту світу [10]. Відтак подальше поглиблення євроінтеграції України матиме низку позитивних наслідків для національної економіки.

Отже, відтік капіталів країн-інвесторів які входять до семи найрозвиненіших країн світу (Німеччини, Великої Британії та Франції), 3 легкістю компенсується капіталом острівних країн (Кіпром).

Якщо дати оцінку позиції України у світових рейтингах, які характеризують ii макроекономічний стан, інвестиційний потенціал та легкість ведення бізнесу, то поки вона $є$ не досить втішною, адже країна займає доволі низькі позиції. Проте, ситуація не $\epsilon$ критичною і 
спостерігається позитивна динаміка. Зокрема, у рейтингу інвестиційної привабливості країн світу International Business Compass за 2015 рік, опублікованому компанією BDO, Україна за рік піднялася на 20 позицій [11]. Україна в рейтингу розташовується на 89 місці і входить до переліку країн, що показали найкраще зростання за рік, нарівні з Білоруссю і Латвією.

Основними проблемами, які негативно сприяють залученню ПІІ в регіони України в сучасних умовах інтеграції у СС є:

- Нерозвиненість інструментів розвитку внутрішнього потенціалу регіонів, а саме регіональних стратегій. У наявних планах регіонального розвитку відсутній системний аналіз внутрішнього потенціалу регіону та визначення способів його використання. Відповідно, проведений у такий спосіб аналіз стану розвитку окремих галузей та сфер діяльності не сприяє розкриттю внутрішнього потенціалу регіонів.

- Падіння обсягів залучення іноземних інвестицій унаслідок погіршення соціально-економічної ситуації в країні та зниження інвестиційної привабливості регіонів Сходу України через бойові дії.

- Нераціональність розподілу ПІІ, що призводить до їх низької віддачі. Протягом тривалого періоду спостерігається концентрація інвестицій у галузях переробної промисловості, фінансовій та страховій діяльності, оптовій та роздрібній торгівлі, ремонту автотранспортних засобів і мотоциклів. Через нерівномірний розподіл інвестицій неможливо досягти успіху в економічному розвитку. Натомість, спостерігається нестача прямих інвестицій у галузях будівництва, сільського, лісового та рибного господарства, через ризикованість та сезонність даних інвестпроектів.

- Неефективність корпоративного управління та корпоративної соціальної відповідальності. В Україні існують проблеми 3 виконанням взаємних зобов'язань, у результаті чого інвестори 3 компаній-резидентів, яких не влаштовує вітчизняне законодавство, намагаються вивести капітал за межі України.

3 регіональної точки зору, у 2016 р. до Дніпропетровської, Донецької, Харківської, Київської, Луганської, Львівської, Одеської, Запорізької, Полтавської, Івано-Франківської областей та до м. Київ надійшло найбільша кількість іноземних інвестицій, частка яких становить 93,7 відсотка від усіх залучених ПІІ. Київ залучив найбільшу частку ПІІ, адже саме в столиці зосереджена ділова активність. Таке спрямування іноземних інвестицій та капітальних інвестицій в регіональному розрізі не сприяє досягнення єдиного рівня соціально-економічному розвитку регіонів та посилює подальше збільшення розриву у їх розвитку та потенціалу.

Якщо розглянути пріоритетні галузі для інвестування, то іноземний капітал сьогодні особливо необхідний у тих сферах економіки України, активізація яких допоможе вивести іiі з кризового стану та зняти соціальне 
напруження в суспільстві. Насамперед, це виробництво продуктів харчування, товарів широкого попиту та послуг, ліків; агропромислове господарство; паливно - енергетичні галузі; розвиток інфраструктури (транспорт, телекомунікації, побутовий сервіс); розвиток готельного господарства i туризму; стимулювання залучення іноземних інвестицій у наукову, науково технічну та інноваційну сфери [12]. Аби розвивалось ефективне, інноваційне виробництво, а не застаріла, екстенсивна промисловість.

Головним прагненням інвестора $є$ мінімізація ризиків та максимізація отриманого прибутку. Вивчення іноземного досвіду та стан інвестиційного клімату дозволяє запропонувати такий спектр для стимулювання залучення ПII:

- Зниження темпів інфляції. Адже знецінення капіталу через галопуючу інфляцію, яка наявна в Україні, інвестиційний імідж погіршується;

- Забезпечення стабільності банківської системи та формування довіри до неї у громадян та інвесторів;

- Мобілізації вільних коштів підприємств і населення на інвестиційні потреби шляхом підвищення процентних ставок по депозитах і внесках;

- Запуску передбаченого законодавством механізму банкрутства;

- Поглиблення інтеграційних процесів з СС.

В умовах посилення конкуренції за прямі іноземні інвестиції у світі значно важливим стає застосування стимулюючих заходів для залучення ПІІ в економіку країни-реципієнта. Спеціальні заходи податкового, фінансового та організаційного характеру покликані поліпшити загальний інвестиційний клімат в країні, посилити інвестиційну привабливість як національної економіки в цілому, так і ії окремих галузей і регіонів.

Висновок. Таким чином проведене дослідження надає можливість констатувати, що українська економіка, перебуваючи у доволі депресивному стані, зараз потребує додаткового капіталу у вигляді притоку іноземних інвестицій аби стабілізувати та збалансувати економічний стан. Реформування економічної системи та подальша інтеграція у Європейський економічний простір вимагає від України впровадження ефективної інвестиційної політики. Наукова новизна отриманих результатів полягає у систематизації результатів дослідження особливостей залучення іноземних інвестицій в нашу державу на сучасному етапі розвитку економічних відносин.

Подальших наукові дослідження мають бути спрямовані на дослідження інституту власності в Україні - як фундаментальної основи створення стабільних та сприятливих інвестиційних умов.

\section{Література:}

1. Investopedia. Foreign Direct Investment - FDI [Електронний ресурс]. - Режим доступу: URL: http://www.investopedia.com/terms/f/fdi.asp.

2. Закон України «Про режим іноземного інвестування» [Електронний ресурс]. - Режим 
доступу: URL: http://zakon5.rada.gov.ua/.

3. Попельнюхов Р.В. Інвестиційна привабливість економіки України (інвестиційний клімат) [Електронний ресурс]. - Режим доступу: URL: http://www.investplan.com.ua/.

4. Євростат [Електронний ресурс]. - Режим доступу: URL: http://ec.europa.eu/eurostat/web/products-datasets/-/tipsii10

5. Державна служба статистики [Електронний ресурс]. - Режим доступу: URL: http://www.ukrstat.gov.ua/

6. UNCTAD World Investment Report http://unctad.org/en/PublicationsLibrary/wir2013overview_ru.pdf.

7. Фатюха Н.Г., Дем'яненко Я.Ю. Стан і перспективи залучення прямих іноземних інвестицій в економіку українисталий розвиток економіки / Н.Г. Фатюха, Я.Ю. Дем'яненко // Міжнародний науково-виробничий журнал Економіка та управління національним господарством, №3, 2014, с. 54-58.

8. Маркевич К.Л. Поточний стан та перспективи прямого іноземного інвестування в економіку України / К.Л. Маркевич. Науковий вісник Мукачівського державного університету, 2015 № 2(4), Ч. 1, с 249-254.

9. International monetary fund [Електронний ресурс]. - Режим доступу : http://www.imf.org/external/pubs/.

10. Огляд світової економіки. Умови ведення бізнесу змінюються: наші прогнози на 2013 p. [Електронний pecypc] / Price water house Coopers. - Режим доступу : http://www.pwc.com/en_UA/ua/.

11. International Business Compass 2015 [Електронний ресурс]. - Режим доступу: URL: http://www.bdo-ibc.com/fileadmin/dokumente/BDO-IBC-Summary-2015_ENG.pdf.

12. Юр'єва Т.Г., Якименко В.В. Пріоритетні сфери, зони та об'єкти іноземного інвестування в Україні / Т.Г. Юр'єва, В.В. Якименко. [Електронний ресурс]. - Режим доступу: URL: www.nbuv.gov.ua/. 